\title{
Medication-assisted treatment for opioid dependence: making a difference in prisons
}

\author{
Anna Pecoraro ${ }^{1,2}$ and George E. Woody ${ }^{1,2 *}$
}

Address: ${ }^{1}$ Department of Psychiatry, University of Pennsylvania, 600 Public Ledger Building, 150 South Independence Mall, West, Philadelphia, PA 19106, USA; ${ }^{2}$ NIDA Clinical Trials Network, Delaware Valley Node, Philadelphia, PA, USA

*Corresponding author: George E. Woody (woody@tresearch.org)

Fl000 Medicine Reports 20II, 3:I (doi:10.34I0/M3-I)

This is an open-access article distributed under the terms of the Creative Commons Attribution-Non Commercial License (http://creativecommons.org/licenses/by-nc/3.0/legalcode), which permits unrestricted use, distribution, and reproduction in any medium, provided the original work is properly cited. You may not use this work for commercial purposes.

The electronic version of this article is the complete one and can be found at: http://fl000.com/reports/m/3/I

\author{
Abstract \\ This article explores the evolving evidence supporting the provision of opioid maintenance therapies \\ to incarcerated populations.
}

As of December 2008, approximately 10 million people around the world were incarcerated [1]. The United States has the highest incarceration rate in the world [1], with more than 2 million incarcerated adults [2], and roughly $50 \%$ of them suffer from substance abuse or dependence [3]. It follows that illicit drug use in prisoners is a huge problem for society as it is linked with the spreading of HIV and other infectious diseases, increased recidivism, and death. However, few prisoners who need treatment for substance abuse actually receive it, with only about $15 \%$ of US prisoners who used drugs in the 30 days prior to incarceration receiving formal substance abuse treatment from trained clinicians [3]. A significant portion of US incarcerated adults have histories of heroin addiction: probably somewhere between $12 \%$ and $15 \%$ of all prisoners [4,5] and nearly $25 \%$ of prisoners in state facilities (i.e., those convicted of more serious offences) [6]. Left untreated or undertreated, withdrawal symptoms and cravings combined with the general availability of drugs in prison contribute to inmates' drug use [7]. The result is the spreading of infectious diseases such as HIV $[11,12]$ through "needle sharing", creating a large-scale public health problem [8]. Heroin use, in particular, also increases recidivism [13] and mortality [14].

Evidence-based research $[9,10]$ clearly demonstrates that opioid maintenance therapy using methadone or buprenorphine effectively reduces heroin use. Because of this, opioid maintenance therapies are currently recommended by the World Health Organization and the United Nations for both general and incarcerated $[15,16,17]$ populations. As of 2008 , although opioid maintenance therapies were available to the general population in 66 countries, only 29 countries had implemented any opioid maintenance therapies in jails or prisons, with only pilot programs and/or limited availability in many places [18-20].

This underprovision of treatment probably stems from the opinion that people who use illegal substances have broken the law and require punishment for misbehavior rather than treatment. However, advances in three related areas have made this argument less tenable. Firstly, there has been a realization that substance use disorders are chronic, brain-based medical disorders with high relapse rates [21,22]; secondly, there has been an increasing emphasis on evidence-based treatments in health care; and thirdly, recent evidence-based research has demonstrated that opioid maintenance therapies reduce heroin use in incarcerated populations as well as the general population. The conceptualization of substance use disorders as chronic medical conditions [23] is supported by molecular and imaging studies that have led the scientific community to view them as brain disorders with genetic contributions [22,24]; this has increased support for the chronic disease model and necessitated efficacious biological treatments. 
Studies with inmates, as well as over 20 years of experience of a methadone maintenance therapy program at Rikers Island jail in New York, have added to opioid maintenance therapy's already extensive evidence base of data on the general population. The first randomized controlled trial of methadone maintenance with prisoners, conducted in 1968 [25], demonstrated impressive results postrelease. Offenders who received methadone maintenance before and after release were significantly less likely to use heroin or reoffend than wait-list controls. The Key Extended Entry Program (KEEP) at Rikers Island has been providing methadone maintenance during incarceration and dedicated treatment program slots postrelease since 1987 [26].

More recent studies have also had encouraging results. A US randomized trial of methadone maintenance initiated before or just after release from prison demonstrated encouraging results [27]. Patients were randomized to (a) counseling during incarceration with instructions to seek treatment upon release; (b) counseling during incarceration with facilitated referral to methadone maintenance upon release; or (c) counseling and methadone maintenance during incarceration, which was continued in the community upon release. Results 12 months after release demonstrated that participants receiving counseling and methadone while in prison were more likely than both of the other groups to be retained in treatment and were less likely to have opioid- or cocaine-positive urines than those in the counseling-only group [28]. An Australian randomized controlled trial also demonstrated reduced rates of heroin use, injection drug use, and syringe sharing among patients receiving methadone maintenance, relative to wait-list controls [29]. Older research evaluations of methadone maintenance programs during incarceration in Australia [30,31], the United States [32], and Canada [33] have also had positive results. A recent systematic review demonstrated that patients receiving opioid maintenance therapies during incarceration had a $55-75 \%$ reduction in injection drug use and a $47-73 \%$ reduction in needle sharing, relative to controls [34].

Although there have been fewer studies of buprenorphine treatment than methadone maintenance with incarcerated patients, results are promising. A randomized controlled trial conducted at the Rikers Island jail in New York [35] compared methadone maintenance to buprenorphine treatment; both treatments were given during incarceration in jail and postrelease. While there were no differences in reported drug use or re-arrest after incarceration, buprenorphine treatment patients were significantly less likely than methadone maintenance patients to withdraw from treatment in jail and had significantly higher attendance at postrelease care. A feasibility study of buprenorphine treatment provided during incarceration and postrelease in Puerto Rico demonstrated that those who completed treatment were significantly less likely than untreated peers to have opioid-positive urine and be involved in self-reported crime [36]. Another study is currently underway in the United States [37].

The findings reviewed here are important because they provide evidence that opioid maintenance therapies for prisoners reduce drug use and act as a disease prevention measure. Now armed with the evidence, we can hope to change attitudes amongst the public and those working in the legal and prison systems to reduce the stigma associated with both addiction and medication-assisted treatments, to change laws and practices on international, national, and local levels, and to implement medication-assisted treatments with extensive follow up/ aftercare for incarcerated individuals with opioid dependence. There is a continuing need for well-designed research studies, preferably randomized controlled trials, to further examine the efficacy of opioid maintenance therapies within specific incarcerated populations because different populations could respond to treatment differently and there could be a need to adapt the treatment to work better with a specific population.

\section{Competing interests}

The authors declare that they have no competing interests.

\section{Acknowledgements}

The authors wish to acknowledge Michelle Ma, BA, for her assistance in carrying out the research for this paper.

\section{References}

I. Walmsley R: World prison population list. $8^{\text {th }}$ Edition. London: International Centre for Prison Studies, King's College; 2008. [http://www.kcl.ac.uk/ depsta/law/research/icps/downloads/wppl-8th_4I.pdf]

2. Bureau of Justice Statistics: Total correctional population. Washington, DC: Office of Justice Programs, Bureau of Justice Statistics; 2008.

3. Mumola CJ, Karberg JC: Drug use and dependence, state and federal prisoners, 2004. Washington, DC: Office of Justice Programs, Bureau of Justice Statistics; 2006.

4. Chaiken JM: Correctional Population of the United States, 1997. Washington, DC: Office of Justice Programs, Bureau of Justice Statistics; 2000.

5. Karberg JC, James DJ: Substance dependence, abuse, and treatment of jail inmates, 2002. Bureau of Justice Statistics Special Report. Washington, DC: Office of Justice Programs, Bureau of Justice Statistics; 2005.

6. Beck A, Gillard D, Greenfeld L, Harlow C, Hester T, Jankowski L, Morton DC, Snell TL, Stephan JJ: Survey of state prison inmates, 199I. Washington, DC: Office of Justice Programs, Bureau of Justice Statistics; 1993. 
7. European Monitoring Centre for Drugs and Drug Addiction: Annual Report 2009: The state of the drug problem in Europe. Luxembourg: Publications Office of the European Union; 2009. [http://www.emcdda.europa.eu/attachements.cfm/att_93236_EN_ EMCDDA_AR2009_EN.pdf]

8. Jürgens R, WHO, UNODC, UNAIDS: Evidence for action technical papers: Interventions to address HIV in prisons. Drug dependence treatments. Geneva: WHO; 2007. [http://whqlibdoc.who.int/publications/2007/978924I595803_eng.pdf]

9. Mattick RP, Breen C, Kimber J, Davoli M: Methadone maintenance therapy versus no opioid replacement therapy for opioid dependence. Cochrane Database Syst Rev 2009, 3:CD002209.

10. Schulte B, Thane K, Rehm J, Uchtenhagen A, Stöver H, Degkwitz P, Reimer J, Haasen C: Review of the efficacy of drug treatment interventions in Europe: Drug Policy and Harm Reduction Report. Hamburg: Center for Interdisciplinary Addiction Research of Hamburg University; 2008.

II. Metzger DS, Woody GE, McLellan AT, O'Brien CP, Druley P, Navaline H, DePhilippis D, Stolley P, Abrutyn E: Human immunodeficiency virus seroconversion among intravenous drug users in and out of treatment: An 18 month prospective follow-up. J Acquir Immune Defic Syndr 1993, 6:1049-56.

12. Emmanuelli J, Desenclos JC: Harm reduction interventions, behaviours and associated health outcomes in France, 1996-2003. Addiction 2005, 100:1690-700.

13. Lind B, Chen S, Weatherburn D, Mattick R: The effectiveness of methadone maintenance in controlling crime: An Australian aggregate-level analysis. $\mathrm{Br}$ J Criminol 2005, 45:20 I-I I.

14. Gibson A, Degenhardt L, Mattick RP, Alin R, White J, O'Brien S: Exposure to opioid maintenance treatment reduces longterm mortality. Addiction 2008, 103:462-8.

15. WHO: WHO Guidelines on HIV and AIDS in Prisons. Geneva: WHO; 1999, [http://data.unaids.org/Publications/IRC-pub0I/jc277-whoguidel-prisons_en.pdf]

16. WHO: Guidelines for the psychosocially assisted pharmacological treatment of opioid dependence. Geneva: WHO; 1999. [http://www.who.int/ substance_abuse/publications/opioid_dependence_guidelines.pdf]

17. UNODC/WHO/UNAIDS: HIVIAIDS prevention, care, treatment, and support in prison settings. Vienna: UN Office on Drugs and Crime; 2006. [http://data.unaids.org/pub/Report/2006/2006070I_hiv-aids_prisons_en. pdf]

18. Larney S, Dolan K: A literature review of international implementation of opioid substitution treatment in prisons: equivalence of care? Eur Addict Res 2009, 15:107-12.

19. Nunn A, Zaller N, Dickman S, Trimbur C, Nijhawan A, Rich JD: Methadone and bupreorphine prescribing and referral practices in US prison systems: Results from a nationwide survey. Drug Alcohol Depend 2009, 105:83-8.

FI000 Factor 6

Evaluated by Bryon Adinoff 09 Oct 2009

20. Rich JD, Boutwell AE, Shield DC, Key RG, McKenzie M, Clarke JG, Friedmann PD: Attitudes and practices regarding the use of methadone in US state and federal prisons. J Urban Health 2005, 82:4II-9.
21. WHO: Neuroscience of psychoactive substance use and dependence. Geneva: WHO; 2004. [http://www.who.int/substance_abuse/publications/en/Neuroscience.pdf]

22. Chandler RK, Fletcher BW, Volkow ND: Treating drug abuse and addiction in the criminal justice system: Improving public health and safety. JAMA 2009, 30I:183-90.

23. McLellan AT, Lewis DC, O'Brien CP, Kleber HD: Drug dependence, a chronic medical illness: Implications for treatment, insurance, and outcomes evaluation. JAMA 2000, 284:1689-95.

24. Uhi GR, Grow RW: The burden of complex genetics in brain disorders. Arch Gen Psychiatry 2004, 6I:223-9.

25. Dole V, Robinson J, Orraca J, Towns E, Searcy P, Caine E: Methadone treatment of randomly selected criminal addicts. N Engl J Med 1969, 280:1372-5.

26. Tomasino V, Swanson AJ, Nolan J, Shuman H: The Key Extended Entry Program KEEP: a methadone treatment program for opiate-dependent inmates. Mt Sinai J Med 200I, 68:I4-20.

27. Gordon MS, Kinlock TW, Schwartz RP, O'Grady KE: A randomized clinical trial of methadone maintenance for prisoners: findings at 6 months post-release. Addiction 2008, 103:1333-42.

28. Kinlock TW, Gordon MS, Schwartz RP, Fitzgerald TT, O'Grady KE: A randomized clinical trial of methadone maintenance for prisoners: Results at $\mathbf{1 2}$ months postrelease. J Subst Abuse Treat 2009, 37:277-85.

29. Dolan KA, Shearer J, MacDonald M, Mattick RP, Hall W, Wodak AD: $A$ randomized controlled trial of methadone maintenance treatment versus wait list control in an Australian prison system. Drug Alcohol Depend 2003, 72:59-65.

30. Wale S, Gorta A: Views of inmates participating in the pilot pre-release methadone program. Process evaluation of New South Wales Department of Corrective Services pre-release methadone program study No 2. Sydney: Research and Statistics Division, New South Wales Department of Corrective Services; 1987.

3I. Dolan K, Hall W, Wodak A: Methadone maintenance reduces injecting in prison. $B M J$ I996, $312: 1 / 62$.

32. Magura $\mathrm{S}$, Rosenblum $\mathrm{A}$, Lewis $\mathrm{C}$, Joseph $\mathrm{H}$ : The effectiveness of injail methadone maintenance. J Drug Issues 1993, 23:75-9.

33. Branch CR: Institutional methadone maintenance treatment: Impact on release outcome and institutional behavior. Ottawa: Correctional Service Canada; 2002.

34. Larney S: Does opioid substitution treatment in prisons reduce injecting-related HIV risk behaviours? A systematic review. Addiction 2010, 105:216-23.

35. Magura S, Lee JD, Hershberger J, Joseph H, Marsch L, Shropshire C, Rosenblum $A$ : Buprenorphine and methadone maintenance in jail and post-release: A randomized clinical trial. Drug Alcohol Depend 2009, 99:222-30.

36. Albizu-Garcia C, Caraballo Correa G, Hernandez Viver AD, Kinlock TW, Gordon MS, Antron Avila C: Buprenorphinenaloxone treatment for pre-release opioid-dependent inmates in Puerto Rico. J Addict Med 2007, 1:126-32.

37. Kinlock TW, Gordon MS, Schwartz RP, Fitzgerald TT: Developing and implementing a new prison-based buprenorphine treatment program. J Offender Rehabil 2010, 49:91-109. 